\title{
Features of Oppression and Wastage Resulting in Liability in the Law and Jurisprudence
}

\author{
Reza Bakhtiyari ${ }^{1} \&$ Alireza Amini ${ }^{1}$ \\ ${ }^{1}$ Faculty of Theology and Philosophy, Islamic Azad University, Science and Research Branch, Tehran, Iran \\ Correspondence: Alireza Amini, Faculty of Theology and Philosophy, Islamic Azad University, Science And \\ Research Branch, Tehran, Iran. E-mail: a-amini@srbiau.ac.ir
}

Received: June 16, 2016 Accepted: July 18, 2016 Online Published: July 31, 2016

doi:10.5539/jpl.v9n6p188 URL: http://dx.doi.org/10.5539/jpl.v9n6p188

\begin{abstract}
The subject of oppression and wastage and liability arising from it, involve a significant part of the relationship between human beings with each other and the relationship between natural and legal persons. This has long been the most important issues and has been subjected to human, and in Islamic jurisprudence considered as the cause and contraption of liability; such a way that sometimes acceptance actions (oppression) and sometimes deprivation actions (wastage) caused harm to others. In law and religion, the rule of acceptance and denial actions has been explicitly stated. However, there are some cases as well which no special rule has been stated for them but in majority cases, omission or doing an action to stave off the losses from other is necessary. So it is necessary the aspects related to this topic to be explained properly. Hence, this question arises, what are the features of oppression and wastage led to liability in jurisprudence and consequently the rights derived from it?

Although in the case law according to the rule of Estimate (asking for something on loan), the liability of the authorized person in possession of the property has been removed despite the oppression and wastage the trustee is considered traitors and bondsman. In fulfillment of oppression and wastage and the liability resulted from that insight and intention of authorized person has no interfered and effect and oppression and wastage are the bases of liability and civil responsibility. Of achievements of this study which has been done descriptive-analytic is introduction and explanation of proper criteria for identifying oppression and wastage in cases where in the law and the jurisprudence have not been mentioned.
\end{abstract}

Keywords: liability, abuse, wastage, civil responsibility, science, mores

\section{The Problem Statement}

One of the necessities of social life is faithful and trustworthiness character. However, considering human progress in most areas and followed by more complex relationships in today's communities, this important issue, unfortunately, has been eroded in the modern world. So, weakening of this vital character brings out disorders and adverse effects on human society that it is necessary this issue be addressed more because there is no doubt that this character of the community would be the cause of peace and tranquility. As bad character breach of trust, insecurity, paranoia, and social ills in the society bring. One of the most important aspects of trusteeship and oppression and wastage which should be addressed well is its jurisprudence and legal aspect, because, in subjected cases and instances of this issue, it should be acted with the law and religious about it. Therefore, in the current study we explore the concept of oppression or wastage; realization and recognition criterion of it and the role of science and intention in the liability caused by it, civil responsibility arising from wastage and the role of mores in the liability of oppression and wastage.

\section{The Meaning of Oppression and Wastage}

Scholars have defined these two words such: oppression is a commitment of an act that its omission is necessary, and wastage is the omission of an act that its commitment is necessary (Sabzsvari, Kefayat-al-Ahkam, p. 133; Maraghi, Al-anavin-al-faqhihieh, vol. 2, p. 447). Or oppression includes doing an act, which leads to waste and wastage includes nonchalance and negligence in the maintain the property or not preventing the waste of property. (Mohaghegh Helli, Sharaye-al(religions)-Islam, vol. 4, p. 1052). Another definition says: oppression is an illegal occupation in the deposit. (Mohaghegh Helli, ibid., Vol. 2, p. 404). To explain these definitions we can say that, oppression achieved once that trustee does an action which considered as infringement from the limit of 
owner's permission or conventional permission. For example, bailee wears the trust clothes, or the authorized person cut the branches of fruit trees and take the fruit to home to eat fruit. The wastage is achieved once for example, with swimming teacher's negligence or indifference, a child drowns in the pool or trustee does not place belong in a convenient location of it and property stolen or animals tenant, refrain giving water and grass to an animal (Toosi, Al-Khalaf, vol 4, p.172). So the difference between oppression and wastage is that there is a kind of passivity or negligence in the sense of wastage while, the sense of oppression includes agency, assault, hatred and extravagant lies. In other words, the former is deprivation and the other acceptance.

\section{The Criteria of Oppression and Wastage}

The first rule is that if the owner with his/her free will and choice and with mutual consent and contract deliver his/her possession to other to maintenance or use, the receiver of the property considered as the trustee and is not responsible for waste or loss of property. According to trusteeship description, the permission can be absolute or conditional (Mohaghegh Helli, ibid, P.106).

If permission is absolute, the authorized person is free in the manner of its capture. While, if permission is restricted, the authorized person or proprietor has no right to act outside the scope of the permission. So, in the case of doubt on the applicability and restriction of an authorized person shall be permitted to occupy in the authorized property or the right conventionally (Mohghegh Bohrani, Al-hadegh-al-Nezarah, p. 106). However, who has occupied in someone else's property with the permission of the owner or the law, his/her occupation is not illegal. whereas, if after the date of the owner's authorization to refrain from rejecting it or deny the existence of property in his/her sight, since the denial is tantamount to the usurper. Article 310 of Civil law, in this case, provides that: "If someone denies the property is in his hand as borrow or deposit and like them, from the date of denial is tantamount to the usurper." One of the contemporary writers has said that the person who seizes others property illegally or makes dishonesty in returning trusted property on time, or denies its existence or in occupying, and commit a fault in maintaining of it and his/her work is not consistent with confiscation, is tantamount to usurpation. (Katouzian, compulsory liability, civil liability, p.379). Consequently the realization criterion of oppression and wastage which indicates the withdrawal of the permission of the owner or Sharia or law or custom (mores) according to the case, thus mere intent to oppression and wastage wouldn't destroy trusteeship until the action. Therefore, some jurists have said: "if one intended to oppress, is not guaranteed the intent until operated" (Allameh Helli, Tahryralahkam, vol. 1, p. 266; Toosi, Al-Khalaf, vol. 4, p. 175). However, with the action that is evidence of oppression or wastage the liability is accrued. Although the action with the intention of oppression not to be permission domain. So, any violation of negligence or fault though as a result of drunk or sleeping or forgetting done, lead to deterioration of trusteeship is tantamount of usurpation or betrayal (Allameh Helli, Tazakaratal-Foghaha, vol. 2, p. 206).

\section{The Criteria of Oppression and Wastage Identification}

In the jurisprudence to distinguish oppression and wastage some regulations have been mentioned that some of them are:

1. Acting or omission of matters are illegal in religious, is the reason of liability. Nevertheless, the matter that is permitted legally does not create responsibility. For example, digging a well in another property (realm) (Fakhr al-Muhaqqiqin, explanation of advantages [Izah-al-favayed], vol. 4, p. 266) or put the stone in the path of people (Mohaghegh Helli, Sharae-Islam, vol. 4, p. 254) is the cause of liability. However, in the permissible actions, if extravagance or misuse of the right exists and cause harm to others, civil liability, and the responsibility arises. For example, someone eats the property of others during times of emergency, is a permissible action but resulted damages and losses should be paid to the owner of the ownership.

2. If an action is conventional and encompassed with interests for individual and society, but cause harm to anyone accidentally, does not cause the civil liability. For example, if one sprinkling in a public road to prevent dust off and someone else slip and damaged the door of it, is not a bailee. But spraying water without any expedient or dropping like a banana peel cause the liability (Khomeini, Tahrir-availeth, vol. 2, p. 565).

3. Although knowledge and intent are not required in the case of oppression and wastage, if we say that knowledge and purpose are effective in achieving it, in this case, a person who knowingly and willingly commits an action which caused losses to others, is considered as bailee. For example, someone lit a fire in his/her house or garden, and after meeting the wish, does not turn off the fire and because of it, the neighbors suffered losses, that is the bailee of that loss. If the waste on the need lit set on a fire and without knowledge or suspected to have caused losses to the neighbors and turned fire because of vain and extravagance it seems both of respect [reverence] and liability are attained (Mohaghegh Ghomi, Jame-alshetat, p. 581). About the liability of the owner to harmful capture to the neighbors, the criterion of the liability resulting from the mores wastage to others 
property, are two things:

A) Knowledge or suspicion to spread the fire to the neighbor's house.

B) The action that owner does is susceptible to injury, although the owner is unaware of it or has suspicion to spread. Therefore, some jurists have said: If someone abandons a wild beast which is aggressive habitually because of omission of reservations will be responsible for the damage. Or make walls of his/her home tends to another real estate would be the bailee of compensation and losses resulting from the fall of the wall. Also, if found the wall in his/her property straight initially, but later be tended (skewed) the public road or other properties (land), removal of it, is necessary to the owner. And if even possible, neglect to removal or amendment of the wall would be bailee(AllamehHelli, Tahryralahkam, vol. 2, p. 265).

4. Doing things against the norm (mores) is one of the principles and criteria for determining of oppression and wastage, however sometimes committing or omission affairs inconsistent with customs could not be religious veneration, but in the case of harmfulness may cause civil liability. In this regard, in another part of this article, we will tell more.

5. Violation of legal regulations: oppression and assault of people from the range which law has determined in many cases, in addition to criminal responsibility, in the event detrimental to others create civil liability as well. The meaning of the law is its broad sense of it that includes all the rules.

\section{The Role of Knowledge and Intention in the Liability of Oppression and Wastage}

One of the issues which in this type of liability cause controversial is the role of knowledge and intention. Some jurists have stated:" the apparent word of oppression and wastage stated by their intent and knowledge. Because a non-intend person is excused (ShahidThani, MasalekAlafham, vol. 2, p. 245; Najafi, Jvaheralklam , Vol 43, p 123). Therefore this category of jurists, have considered knowledge or suspicion of oppression as a condition of liability. The reason of believers in non-liability is the occupant is permitted in possession from the owner or lawyer, and the lack of knowledge and intent in oppression or wastage the originality of exemptions from liability is enacted. However, it is right to be told: in the contractual liability as soon as the committed person refrain to the proper performance of his/her commit to commitment either has intent or knowledge to harm or not, is guilty. This is mere non-performance of the contract create responsibility unless it is proved non-performance of commitment have been due to the interference of foreign forces. Therefore, in civil responsibilities as well, the lawyers and Islamic jurists do not consider the intention, deliberation and guilt the condition to establish responsibility [liability] (Mughniyeh, Fiqh [jurisprudence] al-Imam Ja'far al-Sadiq, p. 85). Moreover, the companions' apparent word is absolute, and all liability causes are oppressive of the rule. Because with non-consensual, the possessor entrance under trusteeship reasons is dubious is. Therefore, the reference, in this case, would be liability rule. Also, by oppression and wastage waste, the case is placed under the reason of waste that there is doubt in non-interference of intention on it. Furthermore, the wasteful is liable for losses, and a waste though has been in asleep or forgotten (MARAGHI, Al-anavynAlfqhyhe [Juridical titles], vol. 2, p. 488). Thus it is the responsibility of the wasteful, however, in the condition of negligence and without free will the waste has occurred. Apparently, in removal tradition, the rule of intention and guilty in waste have no difference, and a waste of other property caused certain responsibilities that guilty or wasteful should assume the compensation of damage.

\section{The Role of Custom (Mores) in the Liability of Oppression and Wastage}

The Sharia (religion), law and contracts are the primary sources of obligations. However, by the sentence of the same Sharia (religion) and law, in many cases, custom in determining rulings and judgments and identifying the subject and the completion and interpretation of rules and explaining concepts and determining the instances and meaning of words, has the main role. For example, distinguishing fungible and guardian objects and recognition of concept and case being oppression (fault) is the task of customs (Articles 950-953 of civil law). Plus the requirements of convinced parties to all results achieved due to custom and habit from contract (Article 220 civil law) occupation on own can't be entailed losses to neighbor unless a rule that as much as conventional (Article 132 civil law). There is also a lot of such these in religious books, Including:

A) The reason of some Juridical Sentences is a just common sense (mores): If someone after a good beginning sells fruit, is required to maintain the trees until the fruit picking. «Our guide on the necessity of keeping: The reference to the habit and the habit of his/her neighbors that the fruits are not be sold. Though to take timely, either prematurely, it did not experience habit (Tusi, Al-Khalaf, vol 2, p. 80; Mohaghegh Helli, the laws of Islam [Sharae-al-Islam], vol 2, p. 282).

B) In the lease contract if its direction not specified and stipulated the application of contract of this topic back to 
what the norm (mores) refers to (Toosi, ibid., P 51).

C) To identify the gauged and weighted objects the base is a just common sense (mores) (Ibn Barraj, Almohzab, vol. 1, p. 363).

D) The mores (custom) recognizes that what women should have a servant and how much and what they will receive as alimony (Ibn Barraj, ibid., Vol. 2, p. 343).

E) In the disputes and conflicts anybody who claims against the customs (mores) and habits have to adduce reason (Mohaghegh Helli, ibid., Vol. 5, p. 116).

F) Determining the meaning and scope of terms such as Relatives, amulet, Revive and arrest (Allamah Hilli, Tazkara-Alfqha', vol. 1, p. 483) is the task if custom and « Usually Sharia, react to people to the custom in which do not put him in the street rude .» (AllamehHelli, ibid., P 476).

G) Rule and criteria in the primacy or recency of foreman or reason in wasting have no reason except mores (custom) order (MARAGHI, ibid., Vol. 2, p. 435). Considering the mentioned cases, we can say the custom (mores) in recognition of the concept and practice of guilt and sentence to a person be guilty has a high status in Islamic jurisprudence and civil law. Thus the criterion (rule) of oppression or wastage is nothing but the custom (mores). So in addition to the illegal actions that have a responsibility, all unconventional actions both deprivation and acceptance alternative that is contrary to certain practices community of and cause losses and harm to other bring liability. The custom (mores) is so flexible and varied that can easily fix the flaws and fragility and uncertainty of the official rules.

In this context, it also has been stated that: "There is no reason logically that doing an action which normal human does not, considered as a fault or, not doing an action which conventional humans do is not considered fault or guilt. However, it should be noted that the judgment of common sense (custom) and ethics must be considered (Katouzian, compulsory liability, tort [civil responsibility, P. 196).

However, just as a violation of the laws is binding (resulted in responsibility), omission or Etyan (bringing of the oath) of actions inconsistent with common sense (mores) can be a liability. Because oppression and wastage injurious to others, except the view of religion, law and customary are strictly prohibited.

For determining the subject of oppression and wastage, the customary criterion should be considered in addition to other criteria. Though available customary practices in everywhere and in any customary (mores) are not evidence of religious orders. But, according to one of the jurists, the customary is considered as one of liability resources " Perhaps it was made in the liability of oppression although not taboo words has been shown by many»"(Ansari, Epistles of Al-faqhiha [Resaelol-faghihia], p. 130). Some other jurists have said: If an action is predictable conventionally and the person, regardless of it, do harmful actions, lack of prediction of the conventional action (wastage) is a fault, and this fault introduces the responsible cause. In addition, determining the responsible cause for the fault with customary rules of identification and finding all the terms and tools of responsible is much easier (Khoei, foundations of Taklemat-Al-menhaj), vol. 2, p. 245).

About the conventional cause, one of the contemporary authors has stated: the theory of general cause traditionally has been accepted by Islamic jurists and lawyers and always in some things have Causer according to the conventional view. Because according to accepted rules and principles the causes and conditions between should be distinguished. Therefore all of terms and events that are leading to inflict losses are not considered as causes (Safa'i, Civil Rights Foundation, vol. 2, p. 565). Article 352 of the Islamic Penal Code is derived from this comment which says as the following sentence. If someone lit a fire in his/her property (land) sufficiently clear and know that not spread to another place and usually does not spread but spread elsewhere accidentally, and cause the loss of or damage will not be responsible (liable).

Inspiring from the provisions of these traditions and legal matters it can be said: In Islamic law and jurisprudence about the liability of wastage and oppression, the criterion is the normal and rational behavior of people. If one is from the Commons public the public customary (mores) and if from special people (doctors, judges, lawyers, architects, etc.) the specials customary (mores) will determine the oppression and wastage and the amount of it.

In short, oppression and wastage are the natural causes of liability and responsibility.

The action outside of limits of current conventional, the law or permission of the property or another right called, and oppression and wastage are the omission of an action that in the virtue of a contract, conventional or law the protection of life or property or another body, is required. But in addition to the permission, the authorized occupation should be associated with interest and owner envy. Otherwise, the authorized will be liable. 
The liability arising from oppression and wastage proving the fault of losses doer and causality between guilty and losses are the condition of responsibility realization. In the case of oppression and wastage, resulting in waste or loss, the existence of knowledge and intent is not required, and wasteful is required to compensate for damage. Because the liability is a statutory rule (order) rather a duty one.

With reliable and trustworthy of the proprietor, a claim for damages is accepted without oppression and wastage from him. Otherwise, it is necessary to prove the absence of fault on him. If the owner doesn't have proof of guilt and no knowledge about the fact, demands an oath from the doer.

\section{Civil Liability Arising from Wastage}

The Article 952 of the civil law states that "the wastage includes omission which is required under a contract or conventional to keep the property of other."Now the question that arises is: why and how to refrain from doing a particular act or omission creates responsibility? This responsibility how can be consistent with the principle of freedom will and actions of people? Why would someone who has not attempted to commit an act is considered responsible, liable and guilty?

Answer: According to the definition of civil law about wastage it can be said that omission might refrain from engaging in a legal contract or obligation or abstain from performing a conventional action. Contractual obligations or contract is a responsibility that goes the parties of contract with the conclusion of the contract and the failure to perform or delay in performing the obligations or doing commitment insufficiently cause damage to the other party. Therefore civil law provides in Article 221:"If someone obligate to do something or commit that refrain from doing something, $\mathrm{n}$ case of violation is responsible for compensation for damages to another party, provided that compensation for the stipulated damage or obligation is commonly referred or based on the rule of law is liability."

In the field of civil liability not doing the legal tasks, without a doubt, is considered as the fault and the abstainer person is the responsible and liable for losses. So with the existence of clear and explicit legal duty for people and neglect and disregard and not doing the duty above, and achieving losses and damage, the person will be responsible for losses.

Also, from the provisions of the civil law, liability resulted from omission clearly concluded. As it is stated in Article 7 of civil liability law: "One who is responsible for maintenance or care of insane or underage or legally or regarding the contract, in the case of negligence in maintenance or care, is liable to compensate the losses incurred to insane or underage." The other cases of liability resulted from omission are in the different laws: In Article 360 and 361 of the Islamic Penal Code and Article 334 of the Civil Code express the responsibility of the owner or possessor of the animal to compensate for damages by animals resulting from negligence and nonchalance in maintaining animal is mentioned. In Article 333 of Civil law has reminded the responsibility of the building or factory owner about the damages with her/his knowledge and lack of care has gone on other.

\section{Conclusion}

The subject of oppression and wastage and liability arising from it, which in Islamic jurisprudence considered as the causes and reasons of liability. Oppression is the commitment of an act that its omission is necessary, and wastage is the omission of an act that its commitment is necessary. So the difference between oppression and wastage is in the sense of wastage there is a kind of passivity or negligence and in the sense of oppression and kind of agency, assault, hatred and extravagant lies. In other words, the former is deprivation and the other acceptance. In law and religion, the rule of acceptance and deprivation actions has been explicitly stated, but there are some cases as well which no special rule has been stated for them but in mores, omission or doing an action to stave off the losses from other, is necessary. Realization criterion of oppression and wastage which indicates the withdrawal of the permission of the owner or Sharia or law or custom (mores) according to the case, thus mere intent to oppression and wastage wouldn't destroy trusteeship until the action. Therefore, any violation of negligence or fault though as a result of drunk or sleeping or forgetting done, lead to deterioration of trusteeship is tantamount to usurpation or betrayal. Among the important factors in the criteria for determining oppression and wastage, are unauthorized practice, intention, and awareness, knowledge and intention and the customary (mores). Of important consequences of oppression and wastage is the liability of them. So, not doing the legal tasks undoubtedly considered as a fault and the abstainer person is the responsible and liable for losses. So with existence of clear and explicit legal duty for people and neglect and disregard and not doing the duty above, and achieving losses and damage, the person will be responsible for losses.

\section{References}

Ansari, Resayel [Epistles] Al-faqhyeh. 
Fakhr al-Muhaqqiqīn, explanation of advantages (Izahol-favaed).

Heilli, Tahryral-ahkam.

Helli, Tazkara- Al-foqhha' (Tazkaratol-foghaha).

Ibn Barraj, Almohazab.

Katouzian, compulsory liability, civil liability.

Khoei, principles of Taklamatol-menhaj.

Khomeini, Tahrir al-vasileh.

Maraghi, Al-anavion-al-feghhia[Titles of jurisprudence].

Mohaghegh Helli, the laws of Islam.

Mohaghegh Qomi, Jame-al-shatat.

Mohaghegh, Bohrani, Al-hadegh-alnazara.

Mughniyeh, Fiqh al-Imam Ja'far al-Sadiq.

Najafi, Jvaheralklam.

Quran Karim.

Sabzevari, Kefayatol-Ahkam.

Safa'i, Foundation of civil law.

ShahidThani, masalek-Alafham.

Toosi, Alkhalaf.

\section{Copyrights}

Copyright for this article is retained by the author(s), with first publication rights granted to the journal.

This is an open-access article distributed under the terms and conditions of the Creative Commons Attribution license (http://creativecommons.org/licenses/by/4.0/). 